\title{
Deployment of Six Sigma Methodology in Pars Plana Vitrectomy
}

\author{
Ibrahim Sahbaz ${ }^{1}$, Mehmet Tolga Taner ${ }^{2, *}$, Huseyin Sanisoglu ${ }^{3}$, Taner Kar $^{4}$, Gamze Kagan ${ }^{5}$, \\ Ebubekir Durmus ${ }^{3}$, Meltem Tunca ${ }^{3}$, Engin Erbas ${ }^{6}$, Ilker Armagan ${ }^{1}$ and \\ Mehmet Kemal Kagan ${ }^{7}$
}

${ }^{1}$ Department of Opticianry, Uskudar University, Istanbul, Turkey

${ }^{2}$ Department of Healthcare Management, Uskudar University, Istanbul, Turkey

${ }^{3}$ Department of Ophthalmology, Haydarpasa Education and Research Hospital, Istanbul, Turkey

${ }^{4}$ Department of Ophthalmology, GATA Haydarpasa Military Education Hospital, Istanbul, Turkey

${ }^{5}$ Department of Occupational Health and Safety, Uskudar University, Istanbul, Turkey

${ }^{6}$ Institute of Health Sciences, Uskudar University, Istanbul, Turkey

${ }^{7}$ Department of Diagnostic Radiology, Siyami Ersek Thoracic and Cardiovascular Surgery Training and Research Hospital, Istanbul, Turkey

\begin{abstract}
Purpose: To show how a Turkish public eye care centre in Turkey initiated Six Sigma principles to reduce the number of complications occurring during and after pars plana vitreoretctomy surgeries.

Method: Data were collected for two years. To analyse the complications among 2272 patients, main tools of Six Sigma's Define-Measure-Analyse-Improve-Control (DMAIC) improvement cycle such as SIPOC table, Fishbone Diagram and, Failure, Mode and Effect Analysis were implemented. Sources and root causes of twenty-two types of complications were identified and reported.

Results: For a successful pars plana vitrectomy procedure, experience of vitreoretinal surgeon, attention of vitreoretinal surgeon, patient's anatomy were determined to be the "critical few" factors whereas, sterilization and hygiene, amount of silicone oil and amount of gas were found to be the "trivial many" factors. The most frequently occurring complication was found to be subconjunctival haemorrhage.

Conclusion: The sigma level of the overall process was measured to be 3.8559 . The surgical team concluded that twelve of the complications should be significantly reduced by taking the necessary preventive measures.

Institutional ethics committee approval has been taken due to retrospective nature of this study.
\end{abstract}

Keywords: Six Sigma, ophthalmology, pars plana vitrectomy, complications.

\section{INTRODUCTION}

In the fourty-four years since its genesis by Machemer, remarkable advances in vitrectomy have established the pars plana vitrectomy as one of the most common intraocular, vitreorenital and microsurgical technique performed in the deeper part of the eye, all of which involve removing some or all of the vitreous, i.e. internal jelly that fills the eye from the iris to the retina $[1,2]$. In the early years, vitrectomy was used to restore ambulatory vision in eyes that were destined to become blind and were related to a large variety of serious complications [1]. As refinements in technique continued and safety of the procedure was established, it has become a widely used technique for the treatment of a variety of blinding disorders e.g. proliferative diabetic retinopathy, complex retinal

*Address correspondence to this author at the Department of Healthcare Management, Uskudar University, Istanbul, Turkey; Tel: 00-90-216-400-2222; Fax: 00-90-216-4741256; E-mail: mehmettolga.taner@uskudar.edu.tr

E-ISSN: 1929-6029/14 detachment, macular hole, epiretinal membrane by removing vitreous opacities, relieving vitrorenital traction, restoring the normal anatomical relationship of the retina and retinal pigment epithelium and accessing the subretinal space [2].

As the scope of vitreoretinal surgical applications increases, so does the potential for complications [3]. Identifying complications and the risk factors associated with them may help reduce the likelihood of poor anatomic or visual results [3]. However, the rate of complications decreased as improvements in technology were introduced [1]. Surgeon skill, experience and training were also significant factors that reduced the rate of complications [1].

Nuclear sclerotic cataract development is the most common complication of pars plana vitrectomy [4]. Within two years of undergoing vitrectomy, more than $90 \%$ of phakic eyes in patient over the age of 50 years will develop visually significant nuclear sclerotic cataract [5]. Evidence suggests that vitrectomy 
increases the long-term risk of open-angle glaucoma by $10-20 \%$ [6]. Other complications of pars plana vitrectomy include retinal tears and detachment, subretinal perfluorocarbon liquid, retinal and vitreous incarceration, endophthalmitis, and recurrent vitreous haemorrhage [2]. Endophtalmitis after vitrectomy is rare but is more commonly found in patients with diabetes and in eyes with retained intraocular foreign bodies [7]. Table 1 lists the common complications of pars plana vitrectomy $[2,3]$.

The use of Six Sigma, as a quality improvement method, can improve the surgical safety, efficiency and accuracy of many ophthalmic surgeries [8]. This study addresses the complications encountered during and after the 2272 vitrectomy procedures performed and outlines the initiation of Six Sigma's DMAIC application in a public eye care centre. Sigma level of each type of complication is also calculated and reported.

Six Sigma, originally initiated by Motorola, Honeywell and General Electric [9], is a powerful performance improvement tool that is changing the face of modern healthcare delivery today [10]. Although it was initially introduced in manufacturing processes [11], it is being implemented in diagnostic imaging processes [12], emergency room [13], paramedic backup [14], laboratory [15], cataract surgery [8], radiology [16], surgical site infections [17], LASIK surgery [18], strabismus surgery [19], intravitreal injections [20], phacoemulsification cataract surgery [21], intraLase surgery [22] and stent insertion [23] as a cost-effective way to improve quality, performance and productivity. This study is the first Six Sigma research on pars plana vitrectomy surgery in the literature.

As a method to eliminate variation, waste, errors and inefficiencies, Six Sigma uses a structured methodology called DMAIC to find the main causes behind problems and to reach near perfect processes. DMAIC is particularly useful to analyse and modify complicated time-sensitive healthcare processes involving multiple specialists and treatment areas by identifying and removing root causes of defects or errors and thus minimizing healthcare process variability $[10,24]$.

Table 1: Common Complications of Pars Plana Vitrectomy

\begin{tabular}{|c|c|c|}
\hline $\begin{array}{c}\text { Complications of intraocular surgery in } \\
\text { general }\end{array}$ & Complications associated with silicone oil & $\begin{array}{l}\text { Complications associated with } \\
\text { intraocular gas }\end{array}$ \\
\hline Endophthalmitis & Glaucoma & Vitreous traction and irritation \\
\hline Sympathetic ophthalmia & Band keratopathy & Retinal breaks \\
\hline \multirow[t]{4}{*}{ Recurrent corneal erosion } & Cataract & Migration of gas \\
\hline & Emulsification & Migration of air \\
\hline & Perisilicone oil proliferation & \\
\hline & Redetachment of the retina & \\
\hline General Intraoperative Complications & General Postoperative Complications & $\begin{array}{l}\text { Complications commonly associated } \\
\text { with pars plana vitrectomy }\end{array}$ \\
\hline Corneal abnormalities & Corneal abnormalities & Postoperative nuclear sclerotic cataract \\
\hline Cataract formation & Cataract & Long-term risk of open-angle glaucoma \\
\hline latrogenic retinal breaks and dialyses & Wound complications & Intraoperative or postoperative retinal break \\
\hline Retinal incarceration & Intraocular fibrin deposition & $\begin{array}{c}\text { Intraoperative or postoperative retinal } \\
\text { detachment }\end{array}$ \\
\hline Choroidal haemorrhage & Periretinal proliferation & Intraoperative cataract \\
\hline Macular phototoxicity & Retinal detachment & Postoperative vitreous haemorrhage \\
\hline Intraocular haemorrhage & Choroidal detachment & Postoperative massive fibrin exudation \\
\hline Hypotony & Intraocular hypertension & $\begin{array}{c}\text { Postoperative anterior segment } \\
\text { neovascularization }\end{array}$ \\
\hline \multirow[t]{4}{*}{ Intraocular hypertension } & Intraocular haemorrhage & \\
\hline & Hypotony and phthisis bulbi & \\
\hline & Endophthalmitis & \\
\hline & Sympathetic ophthalmia & \\
\hline
\end{tabular}




\section{METHODS}

\section{Application of DMAIC for Pars Plana Vitrectomy}

The eye care centre decided that Six Sigma is the best way to achieve their goals. A surgical team is assembled and trained in the methodology. Committed and consistent leadership to overcome the complications is assured by this team. The surgical team firstly generates a SIPOC (Supplier, Input, Process, Output and Customer) table for the pars plana vitrectomy process (Table 2).

During the surgery, various microsurgical instruments are introduced into the vitreous cavity to cut or peel away scar tissue, excise blood, or apply laser treatment. Subsequent to the extraction of the vitreous from the eye, a solution or gas is placed inside the eye.

In their study, Borne et al. [25] concluded that $68 \%$ of the patients had a visual acuity of $20 / 40(6 / 12)$ or better after vitrectomy. Therefore, the surgical team defined the performance objective as patients with higher visual acuity after nearly perfect pars plana vitrectomy procedures. They defined a complication as any unwanted outcome inhibiting the patient to be cured and stable. It compounds the illness and decreases the patient's quality of life or prolongs the planned hospital stay [8]. To achieve the performance objective, the surgical team first determines the Criticalto-Quality (CTQ) factors by brainstorming. The CTQ factors are those factors that may have an influence on the objective.

\section{DISCUSSION}

The surgical team determines the metrics to measure existing process. The metrics to be chosen for a Six Sigma study are as follows:

1. Total number of pars plana vitrectomy procedures performed in the eye care centre,

2. Number of complications occurred during and/or after the procedure.

Data were collected for a period of two-years. In this period, 2272 pars plana vitrectomy procedures were performed. Complications had been noted as they occurred. The surgical team identified twenty-two types of complications and classified them as when they occur (Table 4). Sources (Table 5) and root-causes (Table 6) of these complications are tabulated by type. The type, incidence and severity of complications depend on multiple factors, including the indication for surgery, the underlying ocular and systematic disease the materials and techniques used in surgery and the degree to which the surgical objectives are meet intraoperatively. Thus, the surgery team identified the sources of complications as vitreoretinal surgeon, assistant vitreoretinal surgeon, nurse, patient and intraoperative materials. These sources are evaluated while attempting to assess the root-cause of a complication.

Pars plana vitrectomy is a complex surgery performed as an outpatient fashion by an ophthalmic surgeon with special training on the technique. As new advanced technologies are being introduced, the list of indications grows longer and results improve due to the

Table 2: SIPOC Table for Pars Plana Vitrectomy

\begin{tabular}{|c|c|c|c|c|}
\hline SUPPLIER & INPUT & PROCESS & OUTPUT & CUSTOMER \\
\hline Vitreoretinal surgeon & Patient & Ocular examination & High Visual Acuity & Patient \\
\hline $\begin{array}{l}\text { Assistant } \\
\text { Vitreoretinal } \\
\text { surgeon }\end{array}$ & $\begin{array}{l}\text { Vitrectomy } \\
\text { Equipment }\end{array}$ & $\begin{array}{c}\text { Preparative evaluation by vitreoretinal } \\
\text { surgeon }\end{array}$ & High Vision Quality & \\
\hline Nurse & Microscope & $\begin{array}{c}\text { Examination of medical status and } \\
\text { anesthetic risk }\end{array}$ & & \\
\hline \multirow[t]{5}{*}{ Biomedical Technician } & Endolaser & $\begin{array}{c}\text { Preparation of operational plan by } \\
\text { vitreoretinal surgeon }\end{array}$ & & \\
\hline & Light probe & $\begin{array}{c}\text { Preparation of patient for vitreoretinal } \\
\text { surgery }\end{array}$ & & \\
\hline & & Sterilization of vitrectomy equipment & & \\
\hline & & Vitreoretinal Surgery & & \\
\hline & & Discharge & & \\
\hline
\end{tabular}


Table 3: Indications: Pars Plana Vitrectomy Performed Per Ocular Disease

\begin{tabular}{|c|c|}
\hline & $\%$ \\
\hline \hline Macular epiretinal membranes & 33.46 \\
\hline Retinal detachment & 28.68 \\
\hline Vitreous haemorrhage & 18.75 \\
\hline Idipathic macular holes & 9.19 \\
\hline Vitreomacular traction syndrome & 2.94 \\
\hline IOL drop & 2.20 \\
\hline Penetrane injury & 1.83 \\
\hline Endophtalmitis & 1.47 \\
\hline Premature retinopathy & 0.74 \\
\hline Foreign object in vitreous & 0.37 \\
\hline Chorodial mass & 0.37 \\
\hline
\end{tabular}

experience gained with each new vitroretinal technique. The surgical indications for vitrectomy procedures understudy include a wide range of conditions and are given in Table 2.

The surgical team analysed the occurrence of each complication (Table 4) and related them with the rootcauses on Table 6 . The analysis revealed that Type I, II and III were the three most frequently occurring complications in vitrectomy (Table 7). Then, they classified the CTQs as "vital few factors" and "trivial many factors" according to how frequent they caused the complications. The "vital few" factors, i.e. the factors that had the most impact on the success of vitrectomy were determined to be the experience of vitreoretinal surgeon, experience of vitreoretinal surgeon and patient's anatomy. The other factors, i.e. sterilization and hygiene, amount of silicone oil, and amount of gas were "trivial many".

A Six Sigma process produces 3.4 defective parts per million opportunities (DPMO). Normal distribution

Table 4: Complications Experienced (January 2012 - December 2013)

\begin{tabular}{|c|c|c|c|c|c|c|c|}
\hline & Complication & $\begin{array}{c}\text { Intra- } \\
\text { Operative }\end{array}$ & $\begin{array}{c}\text { Early } \\
\text { Post- } \\
\text { Operative }\end{array}$ & $\begin{array}{c}\text { Post- } \\
\text { Operative }\end{array}$ & Acute & Sub-Acute & Chronic \\
\hline Type I & Posterior synechiae & & & $x$ & & $x$ & $x$ \\
\hline Type II & Intraocular haemorrhage & & & $\mathrm{x}$ & $\mathrm{x}$ & & \\
\hline Type III & latrogenic retinal breaks & $\mathrm{x}$ & & & $\mathrm{x}$ & & \\
\hline Type IV & Retinal redetachment & & & $\mathrm{x}$ & & $\mathrm{x}$ & $\mathrm{x}$ \\
\hline Type V & Cystoid macular edema & & & $x$ & & $\mathrm{x}$ & $\mathrm{x}$ \\
\hline Type VI & Conjunctival haemorrhage & $x$ & & & $\mathrm{x}$ & & \\
\hline Type VII & $\begin{array}{l}\text { Epiretinal and subretinal } \\
\text { membrane }\end{array}$ & $\mathrm{x}$ & & & & $\mathrm{x}$ & $\mathrm{x}$ \\
\hline Type VIII & Glaucoma & & & $x$ & $\mathrm{x}$ & $\mathrm{x}$ & $\mathrm{x}$ \\
\hline Type IX & Hypertony & & $\mathrm{x}$ & & $\mathrm{x}$ & & \\
\hline Type X & Cataract & & & $x$ & $x$ & $x$ & $x$ \\
\hline Type XI & latrogenic retinal hemorrhage & $\mathrm{x}$ & & & $\mathrm{x}$ & & \\
\hline Type XII & Hypotony & & $\mathrm{x}$ & & $x$ & & \\
\hline Type XIII & $\begin{array}{c}\text { Silicone oil into anterior } \\
\text { chamber }\end{array}$ & & & $\mathrm{x}$ & & $\mathrm{x}$ & $\mathrm{x}$ \\
\hline Type XIV & $\begin{array}{c}\text { Migration of gas into anterior } \\
\text { chamber }\end{array}$ & & & $\mathrm{x}$ & & $\mathrm{x}$ & $\mathrm{x}$ \\
\hline Type XV & IOL dislocation & $x$ & & $\mathrm{x}$ & $\mathrm{x}$ & $\mathrm{x}$ & \\
\hline Type XVI & $\begin{array}{l}\text { Complete dislocation of the IOL } \\
\text { into the vitreous cavity }\end{array}$ & $\mathrm{x}$ & & & $\mathrm{x}$ & & \\
\hline Type XVII & Posterior capsular tear & $\mathrm{x}$ & & & $\mathrm{x}$ & & \\
\hline Type XVIII & latrogenic retinal detachment & $x$ & & & $x$ & & \\
\hline Type XIX & Endophthalmitis & & & $\mathrm{x}$ & $\mathrm{x}$ & $\mathrm{x}$ & \\
\hline Type XX & Escape of gas & & & $x$ & $\mathrm{x}$ & $x$ & \\
\hline Type XXI & Expulsive haemorrhage & $\mathrm{x}$ & & & $\mathrm{x}$ & & \\
\hline Type XXII & Choroidal detachment & $\mathrm{x}$ & & & $\mathrm{x}$ & $\mathrm{x}$ & \\
\hline
\end{tabular}


Table 5: Sources of Complications

\begin{tabular}{|c|c|c|c|c|c|}
\hline & $\begin{array}{c}\text { Vitreoretinal } \\
\text { Surgeon }\end{array}$ & $\begin{array}{c}\text { Assistant } \\
\text { Vitreoretinal } \\
\text { Surgeon }\end{array}$ & Nurse & Patient & $\begin{array}{c}\text { Intraoperative } \\
\text { Materials }\end{array}$ \\
\hline Type I & & & & $x$ & \\
\hline Type II & $x$ & & & $x$ & \\
\hline Type III & $x$ & & & & \\
\hline Type IV & $x$ & & & $x$ & \\
\hline Type V & & & & $x$ & \\
\hline Type VI & $x$ & & & $x$ & \\
\hline Type VII & & & & $x$ & \\
\hline Type VIII & $x$ & & & $x$ & \\
\hline Type IX & $x$ & & & $x$ & $x$ \\
\hline Type X & $x$ & & & & $x$ \\
\hline Type XI & $x$ & & & & $x$ \\
\hline Type XII & $x$ & & & $x$ & $x$ \\
\hline Type XIII & $x$ & & & & \\
\hline Type XIV & $x$ & & & & \\
\hline Type XV & $x$ & & & & $x$ \\
\hline Type XVI & $x$ & & & $x$ & \\
\hline Type XVII & $x$ & & & $x$ & \\
\hline Type XVIII & $x$ & & & & \\
\hline Type XIX & $x$ & $x$ & $x$ & & \\
\hline Type XX & $x$ & & & $x$ & \\
\hline Type XXI & & & & $x$ & \\
\hline Type XXII & & & & $x$ & \\
\hline
\end{tabular}

underlies Six Sigma's statistical assumptions. An empirically-based 1.5 sigma shift is introduced into the calculation. To calculate the DPMO, two distinct datasets are required:

$A=$ Total number of pars plana vitrectomy procedures performed.

$\mathrm{B}=$ Total number of complications occurred.

The DPMO formula is:

$$
\mathrm{DPMO}=\mathrm{B} \times 1,000,000 / \mathrm{A}
$$

The higher level of sigma after the initiation of Six Sigma indicates a lower rate of complications and a more efficient process.

The surgical team calculated the current Defects per One Million Opportunities (DPMO) and sigma levels for each complication type (Table 7). The process sigma level, calculated as the arithmetic average of twenty-two complications, was found to be 3.8559 .

The highest sigma level was obtained for Type XXII. The lowest sigma level was found to be of Type VI. Having sigma levels lower than 4.00, the complications of Type I, II, III, IV, V, VI, VII, VIII, IX, X, XI and XII need to be reduced.

Risk assessment of the pars plana vitrectomy was achieved by the failure mode and effect analysis (FMEA). Utilization of the FMEA involved break down the process into individual steps: potential failure modes (i.e. complications), severity score, probability score, hazard score, criticality and detection, so that the surgery team could look at key drivers in the process based on the past experience.

Complication trends and their consequences over a two-year period had been monitored and recorded. Surgical team prioritized the complications according to 
Table 6: Root-Causes of Complications

\begin{tabular}{|c|c|c|c|c|c|c|}
\hline & $\begin{array}{l}\text { Experience of } \\
\text { Vitreoretinal } \\
\text { surgeon }\end{array}$ & $\begin{array}{l}\text { Attention of } \\
\text { Vitreoretinal } \\
\text { surgeon }\end{array}$ & $\begin{array}{l}\text { Sterilization } \\
\text { And Hygiene }\end{array}$ & $\begin{array}{l}\text { Patient's } \\
\text { Anatomy }\end{array}$ & $\begin{array}{c}\text { Amount of Intraocular } \\
\text { Gas }\end{array}$ & $\begin{array}{l}\text { Amount of } \\
\text { Silicone Oil }\end{array}$ \\
\hline Type I & & & & $x$ & & \\
\hline Type II & $x$ & $x$ & & $x$ & & \\
\hline Type III & $x$ & $x$ & & & & \\
\hline Type IV & $x$ & $x$ & & $x$ & & \\
\hline Type V & & & & $x$ & & \\
\hline Type VI & $x$ & $x$ & & $x$ & & \\
\hline Type VII & & & & $x$ & & \\
\hline Type VIII & $x$ & $x$ & & $\mathrm{x}$ & & \\
\hline Type IX & $\mathrm{X}$ & $x$ & & $\mathrm{x}$ & $\mathrm{X}$ & $\mathrm{x}$ \\
\hline Type X & $x$ & $x$ & & & $x$ & $x$ \\
\hline Type XI & $\mathrm{x}$ & $x$ & & & $x$ & $\mathrm{x}$ \\
\hline Type XII & $x$ & $x$ & & $x$ & $x$ & $x$ \\
\hline Type XIII & $x$ & $x$ & & & & \\
\hline Type XIV & $x$ & $x$ & & & & \\
\hline Type XV & $x$ & $x$ & & & $x$ & $\mathrm{X}$ \\
\hline Type XVI & $x$ & $x$ & & $\mathrm{x}$ & & \\
\hline Type XVII & $x$ & $x$ & & $x$ & & \\
\hline Type XVIII & $x$ & $x$ & & & & \\
\hline Type XIX & $x$ & $x$ & $\mathrm{x}$ & & & \\
\hline Type XX & $\mathrm{x}$ & $x$ & & $x$ & & \\
\hline Type XXI & & & & $x$ & & \\
\hline Type XXII & & & & $x$ & & \\
\hline
\end{tabular}

Table 7: Cumulative Frequency, DPMO and Sigma Levels

\begin{tabular}{|c|c|c|c|c|}
\hline & Count & Frequency (\%) & DPMO & Sigma Level \\
\hline \hline Type I & 119 & 5.24 & 52377 & 3.12 \\
\hline Type II & 113 & 4.97 & 49736 & 3.15 \\
\hline Type III & 105 & 4.62 & 46215 & 3.18 \\
\hline Type IV & 69 & 3.04 & 30370 & 3.38 \\
\hline Type V & 64 & 2.82 & 28169 & 3.41 \\
\hline Type VI & 687 & 30.24 & 302377 & 2.02 \\
\hline Type VII & 45 & 1.98 & 19806 & 3.56 \\
\hline Type VIII & 44 & 1.94 & 19366 & 3.57 \\
\hline Type IX & 38 & 1.67 & 16725 & 3.63 \\
\hline Type X & 21 & 0.92 & 9243 & 3.86 \\
\hline Type XI & 17 & 0.75 & 7482 & 3.93 \\
\hline Type XII & 15 & 0.66 & 6602 & 3.98 \\
\hline Type XIII & 12 & 0.53 & 5282 & 4.06 \\
\hline Type XIV & 11 & 0.48 & 4842 & 4.09 \\
\hline Type XV & 7 & 0.31 & 3081 & 4.24 \\
\hline Type XVI & 4 & 0.18 & 1761 & 4.42 \\
\hline Type XVII & 4 & 0.18 & 1761 & 4.42 \\
\hline Type XVIII & 4 & 0.18 & 1761 & 4.42 \\
\hline Type XIX & 4 & 0.18 & 1761 & 4.42 \\
\hline Type XX & 3 & 0.13 & 1320 & 4.51 \\
\hline Type XXI & 2 & 0.08 & 880 & 4.63 \\
\hline Type XXII & 1 & 0.04 & 440 & 4.83 \\
\hline & & & & \\
\hline
\end{tabular}


Table 8: FMEA Table

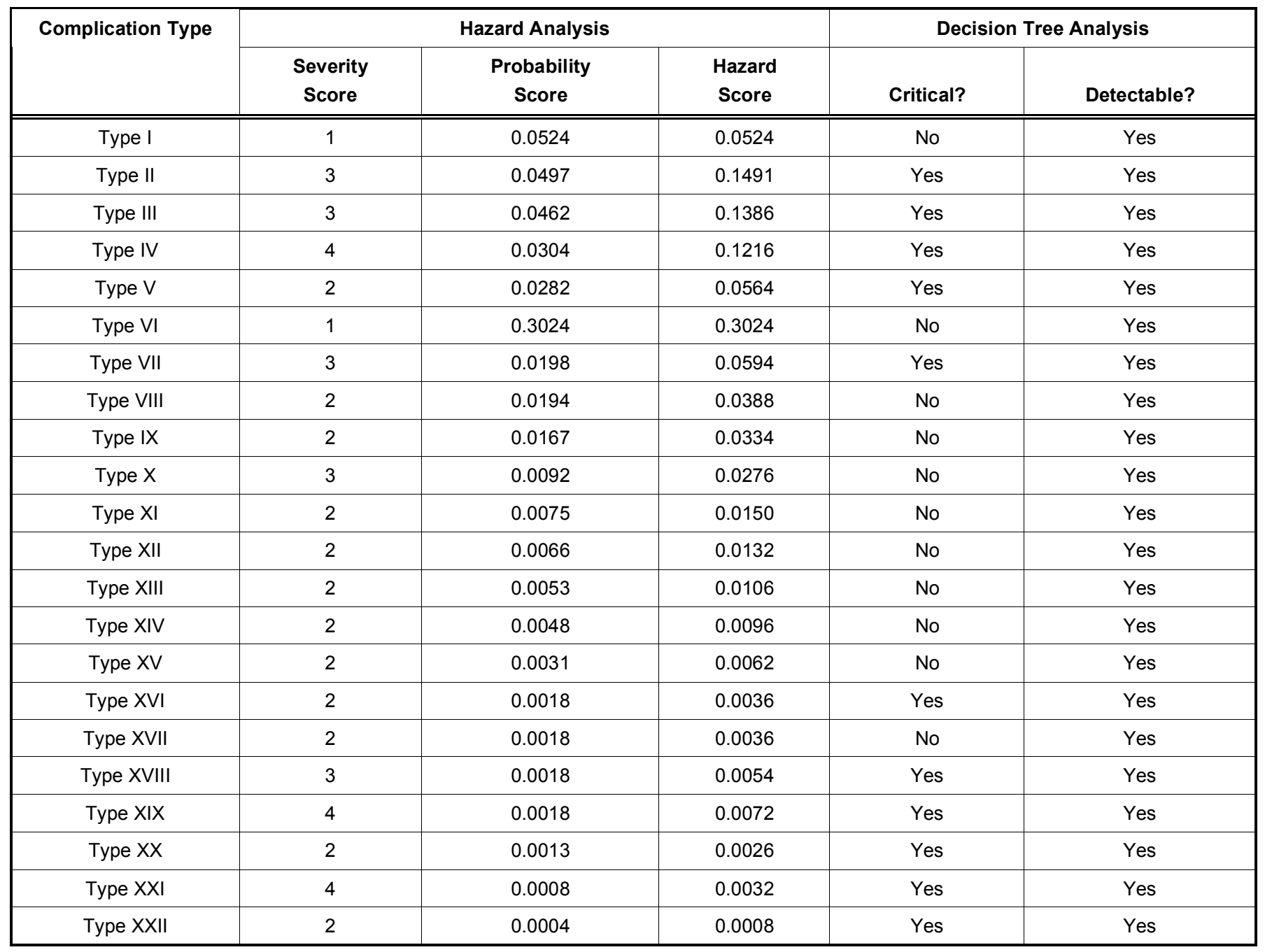

how serious their consequences were (i.e. severity score), how frequently they occurred (probability score) and how easily they could be detected. Hazard analysis was employed in order to identify failure modes and their causes and effects. The surgery team determined the severity of each complication and assigned scores for them. The severity of each complication was scored from 1 to 4 ( $4=$ Permanent harm; $3=$ Temporary harm; $2=$ Bias; $1=$ No harm).

For each complication type, the hazard score was calculated by multiplying the severity score with the probability score. Consequently, an FMEA table was drawn (Table 8). Among the complications, Type VI yielded the highest hazard score. Being greater than 0.1 , Type II, III and IV were also complications with high hazard scores. The results showed that Type XVI and Type XVII were equally hazardous complications. According to FMEA, Type XXII was the least hazardous complication.

\section{Corrective Action Plan}

The surgical team developed preventive measures for each type of complication in order to bring the overall pars plana vitrectomy process under control. They implemented the following corrective action plan to reduce and/or eliminate other complications (Table 9).

\section{RESULTS}

This study investigated the pars plana vitrectomy complications, their types, their sigma levels in current practice and the CTQ factors affecting the process. Twenty-two types of complications were identified. Intraoperative complications occurred with higher frequency than post-operative complications. The sigma level of the overall process was measured and found to be 3.8559 . 
Table 9: Preventive Measures Per Complication Type

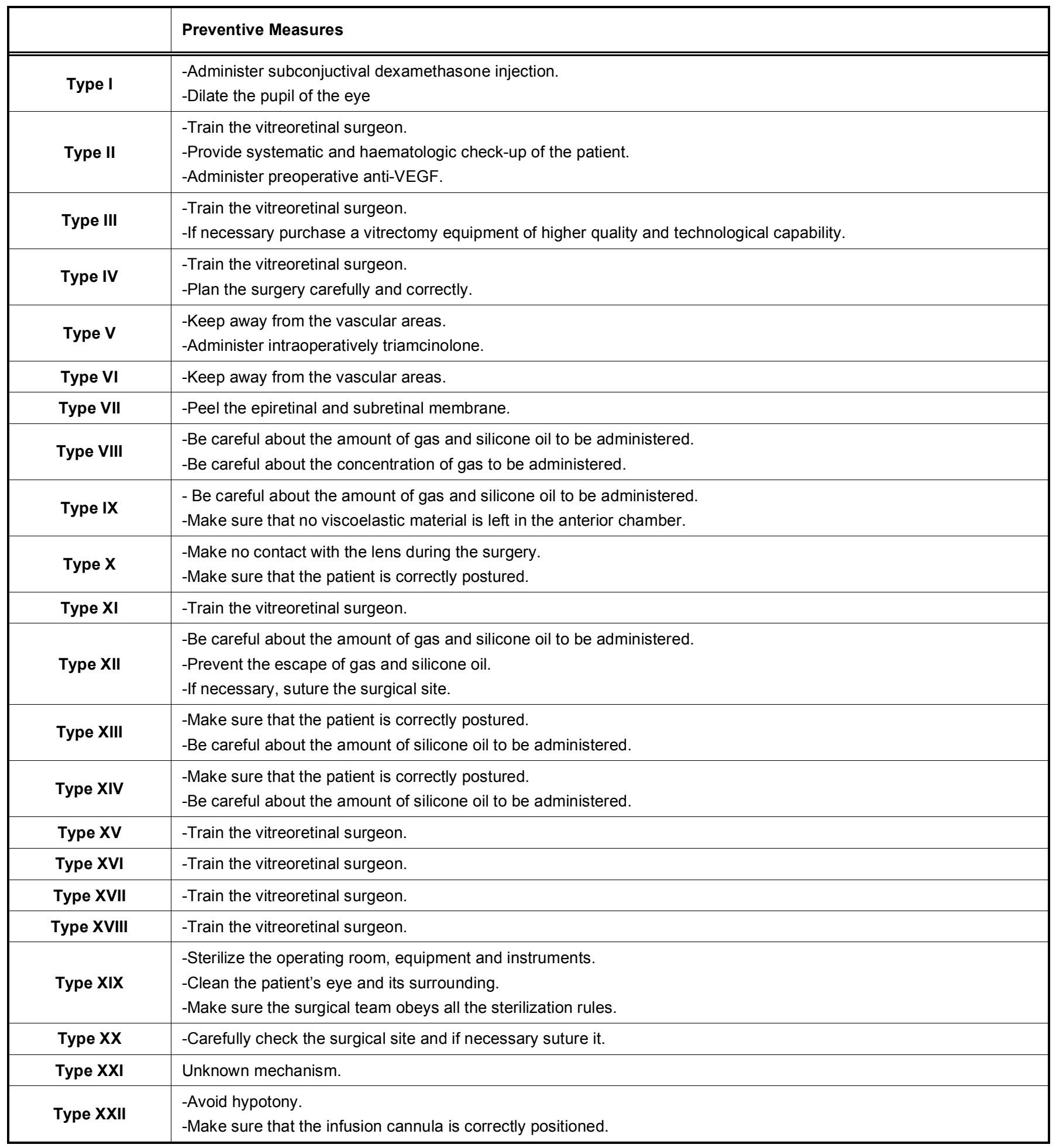

The experience of vitreoretinal surgeon, attention of vitreoretinal surgeon, patient's anatomy, sterilization and hygiene, amount of silicone oil and amount of gas were identified to be the factors affecting the success of pars plana vitrectomy procedures. Surgeon skill, experience and training were also significant factors that reduced the rate of complications. To increase the surgical success rate, it is concluded that twelve complications (out of twenty-two), which had sigma levels smaller than 4.00, should be significantly reduced by taking the necessary preventive measures presented in Table $\mathbf{9}$. 


\section{REFERENCES}

[1] Chang S. Vitrectomy in Ophthalmology, Yanoff M, Duker JS Eds. $2^{\text {nd }}$ ed., Mosby Elsevier Inc.: Spain 2004; Chapter 104: pp. 792-5.

[2] Regillo CD, Ed. Basic and clinical science course. Section 12: Retina and Vitreous, American Academy of Ophthalmology, Canada 2013; pp. 345-69.

[3] Charlton JF, Weinstein GW. Ophthalmic Surgery Complications: Prevention and Management. Lippincott Williams and Wilkins 1995.

[4] Sinha S. Minimally Invasive Vitreous Surgery: 20 Gauge to 27 Gauge, JayPee Medical Publishers, New Delhi 2013; p. 103.

[5] Cherfan GM, Michels RG, De Bustros S, Enger C, Glaser BM. Nuclear sclerotic cataract after vitrectomy for idiopathic epiretinal membranes causing macular pucker. Am J Ophthal 1991; 111(4): 434-8.

[6] Chang S, LXIII Edward Jackson lecture: Open Angle Glaucoma after Vitrectomy. Am J Ophthalmol 2006; 141(6): 1033-43.

http://dx.doi.org/10.1016/..ajo.2006.02.014

[7] Endophthalmitis Vitrectomy Study Group, Results of the Endophthalmitis Vitrectomy Study A randomized trial of immediate vitrectomy and of intravenous antibiotics for the treatment of postoperative bacterial endophthalmitis. Arch Ophthalmol 1995; 113(12): 1479-96.

http://dx.doi.org/10.1001/archopht.1995.01100120009001

[8] Taner MT. Application of Six Sigma Methodology to a cataract surgery unit. IJHCQA 2013; 26(8): 768-85.

[9] Mehrjerdi YZ. Six Sigma: Methodology, Tools and its Future. IJAA 2011; 31(1): 79-88.

[10] Taner MT, Sezen B, Antony J. An overview of Six Sigma Applications in Healthcare Industry. IJHCQA 2007; 20(4): 329-40.

[11] Taner MT. Critical Success Factors for Six Sigma Implementation in Large-scale Turkish Construction Companies. IRMM 2013; 3(4): 212-25.

[12] Taner MT, Sezen B, Atwat KM. Application of Six Sigma Methodology to a Diagnostic Imaging Process. IJHCQA 2012; 25(4): 274-90

[13] Miller MJ, Ferrin DM, Szymanski JM. Simulating Six Sigma Improvement Ideas for a Hospital Emergency Department.
Proceedings of the IEEE Winter Simulation Conference, New Orleans, December 7-10, 2003; pp. 1926-9.

[14] Taner MT, Sezen B. An application of Six Sigma methodology to turnover intentions in health care. IJHCQA 2009; 22(3): 252-65.

[15] Nevalainen D, Berte L, Kraft C, Leigh E, Picaso L, Morgan T. Evaluating Laboratory Performance on Quality Indicators with the Six Sigma Scale. Arch Pathol Lab Med 2000; 124(4): 516-9.

[16] Cherry J, Seshadri S. Six Sigma: using statistics to reduce process variability and costs in radiology. Rad Manag 2000; 22(6): 42-9.

[17] Pexton C, Young D. Reducing Surgical Site Infections through Six Sigma and Change Management. PSQH 2004; 1(1): 1-8.

[18] Taner MT, Kagan G, Sahbaz I, Erbas E, Kagan SB. A Preliminary Study for Six Sigma Implementation in Laser in situ Keratomileusis (LASIK) Surgeries. IRMM 2014; 4(1): 2433

[19] Taner MT, Sahbaz I, Kagan G, Atwat K, Erbas E. Development of Six Sigma Infrastructure for Strabismus Surgeries. IRMM 2014; 4(1): 49-58.

[20] Sahbaz I, Taner MT, Eliacik M, Kagan G, Erbas E, Enginyurt $\mathrm{H}$. Deployment of Six Sigma Methodology to reduce complications in intravitreal injections. IRMM Marketing 2014 4(2): 160-6.

[21] Sahbaz I, Taner MT, Kagan G, Sanisoglu H, Erbas E, Durmus E, Tunca M, Enginyurt H. Deployment of Six Sigma Methodology in Phacoemulsification Cataract Surgery. IRMM 2014; 4(2): 123-31.

[22] Sahbaz I, Taner MT, Eliacik M, Kagan G, Erbas E, Enginyurt $\mathrm{H}$. Adoption of Six Sigma's DMAIC to reduce complications in IntraLase surgeries. IJSMR 2014; 3(2): 1-8.

[23] Taner MT, Kagan G, Celik S, Erbas E, Kagan MK. Formation of Six Sigma Infrastructure for the coronary stenting process. IRMM 2013; 3(4): 232-42

[24] Buck C. Application of Six Sigma to Reduce Medical Errors Annual Quality Congress Proceedings, April 11-15, 2001; Charlotte, pp. 739-42.

[25] Borne MJ, Tasman W, Regillo C, Malecha M, Sarin L, Outcomes of vitrectomy for retained lens fragments. Ophthalmology 1996; 103(6): 971-6. http://dx.doi.org/10.1016/S0161-6420(96)30577-0

(c) 2014 Sahbaz et al.; Licensee Lifescience Global.

This is an open access article licensed under the terms of the Creative Commons Attribution Non-Commercial License (http://creativecommons.org/licenses/by-nc/3.0/) which permits unrestricted, non-commercial use, distribution and reproduction in any medium, provided the work is properly cited. 